\title{
The Mobile Learning Adoption Model Tailored to the Needs of a Private University
}

\author{
Małgorzata Rataj and Joanna Wójcik \\ University of Information Technology and Management in Rzeszow, Poland \\ mrataj@wsiz.rzeszow.pl \\ jwojcik@wsiz.rzeszow.pl \\ DOI: 10.34190/EJEL.20.18.4.004
}

\begin{abstract}
The mission of today's universities is to prepare the students properly to live and work in the 21st century. International research demonstrates the positive impact of using iPads in teaching. Successful deploying of mobile learning ( $m$-learning) is not a matter of accident, but depends on users' acceptance of the technology. The purpose of this article is to create a mobile learning adoption pre-model tailored to the needs of a private university. To achieve this goal, valued adoption models were analyzed and, on their basis, the new model was created. The pre-model has been tested with a questionnaire. A paper-based survey was conducted among 640 students representing 25 countries. The questionnaire was grouped into sections: specifications of mobile devices owned by students and mobile internet access, expectation from mobile education application and attitudes towards current and future use of mobile devices in education. We computed all data with The Statistical Package for the Social Sciences - IBM SPSS Statistics version 25. The results of the research showed that the students from a central-eastern European University are technologically ready for mobile learning. Moreover, there appears to be no cause for concern regarding students from post-Soviet countries with respect to their competency to meet the demands of modern teaching in the form of mobile learning. Students have shown that they have clearly defined expectations for educational materials for mobile devices, which will be a challenge for the university when creating $\mathrm{m}$ learning materials. Furthermore, students must feel the university's support in using mobile applications. That is why the teachers face a serious task: teachers must be prepared to show students the benefits of mobile learning, so they not only need to be trained but also convinced that it is worth using mobile learning.
\end{abstract}

Keywords: mobile learning, e-learning, educational system, attitude, mobile devices, educational application, university management.

\section{Introduction}

The use of mobile devices has penetrated almost every stage of life in today's modern societies (Fiallos, et al., 2017). It has become common, for example, in such areas as public administration, bank accounts, health service and also in education (Al-Emran, Elsherif and Shaalan, 2016). In this paper we explore the factors of mobile learning (m-learning) adoption at the University of Information Technology and Management (UITM), a private university in Rzeszow, Poland. Located in the southeast of the country, the University has 5,157 students from three continents: Eurasia, Africa, and North America.

In the task of exploring the issue of mobile education we were motivated by four factors:

- the rapid growth of the number of mobile devices in the world (Report, 2019),

- the rapid development of mobile education applications - this development is forcing university authorities to create pedagogical strategies to implement m-learning in classes,

- the lack of research data at a national level about m-learning initiatives at universities, with only a few small-scale trials implementing m-learning (Korniejenko, 2016),

- several international reports that indicate the positive impact of iPad use in teaching and learning (Hopkins and Burden, 2014).

To be able to explore the issue of mobile learning adoption by students we begin by a brief review of the literature about dynamic development of mobile devices and their applications. The critical analysis of literature sources familiarized us with present-day solutions, strategies, good practices, mobile learning adoption models used at universities worldwide. The empirical study investigates whether UITM students are technologically prepared for m-learning. Are we able to catch up to universities in highly developed countries? Are we able to implement at UITM good practices in mobile learning from other universities? (Macleod and Kefallonitis, 2017).

Both authors of this article are in charge of implementing new technologies at the UITM. E-learning at UITM is part of an organized didactic process under the supervision of academic teachers. The full integration of the university management information system with the e-learning platform (single sign-on for authentication) 
allows for effective management of the teaching process. Since 1999 about $15 \%$ of all lessons in the UITM curriculum have an e-learning form. For the last nine years we have been using the e-learning platform Blackboard (version 9.1), an obligatory didactic tool. All academic teachers use it to made support materials and assignments accessible to the students. At the UITM an educational platform Blackboard has the following modules implemented:

- Course Delivery - allows the teacher to create and deliver an attractive course content with personalized learning paths, tests, and assessments.

- Content Management - enables the creation of a central repository of didactic materials. This feature facilitates searching for and cataloguing materials, and allows multiple teachers to reusing the same teaching resources.

- Outcomes Assessment - enables data collection and monitoring of students' achievements, the involvement of lecturers and allows automatic assessment of learning outcomes and sending warnings in case of poor results.

- Community Engagement - provides schools with tools to inform community members of the latest news, schedules, and other important information (depending on the role in the organization). It also facilitates creating pages for students' organizations, faculties and organizational units of the university.

Because of the observed changes in student behaviour during their courses (namely logging in from mobile devices even during classes), in the academic year 2019/2020, the university will launch the latest mobile version of the e-learning system. Because the use of the platform is mandatory, the mobile version meets the expectations of mobile users. Students will use the Blackboard application tailored especially for them. The application is available on iOS and Android mobile devices. The University will also provide an Academic Community with a real-time videoconferencing tool called Blackboard Collaborate, which lets teachers add files, share applications, and use a virtual whiteboard to interact.

The strategy presented in this article is part of a two-year research project: the adoption of a mobile solution in the context of university teaching. The project was financed by a statutory grant from the University of Information Technology and Management in Rzeszow, Poland. The study results will help us to decide whether the university is ready - from the students' perspective - to use mobile devices in an educational context. The survey was approved and supported by university authorities, educational experts and the ethics body of UITM.

\section{Literature review}

The m-learning area has become a dynamically developing area of research. Introducing mobile devices in the learning and teaching process require considering the technological trends. M-learning is not only used in the formal education but also is used in informal education in the workplace or in museum institutions (Liu, Han and $\mathrm{Li}, 2010$ ). Research on mobile learning sped up in 2008, probably because of technological changes (Hwang and Tsai 2011). However, as Grant (2019) points out, the concept of mobile learning is applied broadly and relatively imprecisely. The author has reviewed the literature and identified four categories of definitions including relationship to distance education and e-learning, exploitation of devices and technologies, mediation with technology, and nomadic nature of learner and learning.

Considering the wide use of e-learning systems often with mobile versions, it is necessary to define what exactly mobile learning is. According to articles containing a review of literature on m-learning, most studies used mobile devices primarily to stimulate motivation and strengthen engagement, and secondly as a tool for delivering content. Some studies focused on the communication and cooperation that enable mobile devices (Frohberg, Göth and Schwabe , 2009). Features of mobile devices such as portability, continuous connection to the Internet and the ability to check the accuracy of information affect the way people both teach and learn - these features of mobile devices lead to research on the advantages of mobile devices in teaching, challenges resulting from mobile learning and changes that mobile devices will introduce into pedagogy (Gikas and Grant, 2013). As it turns out, the high expectations toward mobile devices, including educational applications, are not always the same, particularly between teachers and students (Montrieux and Schellens, , 2018). Teaching strategies that can be naturally supported are those based on a collaboration like storytelling (Cole H. and Stanton, 2003). The problem may be that while it supports collaborative learning, mobile technology can distract students during the lesson. Critical thinking levels are also lower among students making notes on a mobile device than among those handwriting the notes (Heflin, Shewmaker and Nguyen, 2017). Crompton and Burk (2018) analysed 
research concerning higher education (51.98\% of studies involving mobile learning are in the context of higher education). Most of the analysed studies concerned the impact of mobile learning on student achievement, and the most-studied field was that of foreign languages. Taiwanese researchers have been analyzing articles from 2003-2010 regarding mobile learning and found that the most common research purpose was effectiveness of m-learning (58\%), the design of mobile learning systems (32\%), the affective domain during mobile learning (5\%) and "evaluating the influence of learner characteristics in the mobile learning process (5\%).. In the same article research shows that the surveys and experiments were basic research methods. They also noticed that $86 \%$ of the analysed studies show positive results for mobile learning, and only $4 \%$ are neutral and $1 \%$ negative (this applies mainly to older studies). Another meta-analysis (Sung, Chang and Liu , 2016) with 110 experimental and quasi-experimental articles from magazines published in the years 1993-2013 showed that "the overall mean effect size for learning achievement in this meta-analysis was 0.523, meaning that learning with mobiles is significantly more effective than traditional teaching methods that only use pen-and-paper or desktop computers. "A large group of research concerns the use of mobile learning to teach science (this area is just behind foreign languages). Research shows (Bano, et al., 2018) that mobile applications are under-used in mathematics and science education.

A few models have been developed to test the intention to adopt new technologies - used also in mobile learning. The most known models are The Technology Acceptance Model (TAM), the Unified Theory of Acceptance and Use of Technology (UTAUT) and Theory of Planned Behavior (TPB).

TAM model was originally created to check why people accept or reject computers (Davis, Bagozzi and Warshaw, 1989). Hamidi and Chavoshi (2018) using the TAM model show seven main factors related to the adoption of mobile learning in higher education: ease of use, trust, characters and personal qualities, context, perceived usefulness, behavioural intention, and culture of using.

The most widely used model in the field of information and communication technology acceptance is UTAUT which was developed by in 2003 (Venkatesh et al., 2003). Venkatesh defined main factors of UTAUT such as performance expectancy, effort expectancy, social influence, facilitating conditions, behavioural intention. The research conducted by Nassuora (2012) used the extended model UTAUT, and its results showed a positive attitude that led to the behavioural intention to use m-Learning.

The University of Coimbra also carried out a research study about the different factors that could accommodate drivers and influence students' behaviour towards the use of mobile technologies for learning. Their findings were based on a quantitative survey grounded in the Technology Acceptance Model and the Unified Theory of Acceptance and Use of Technology (Briz-Ponce,et al., 2017).

The Theory of Planned Behaviour was proposed by Icek Ajzen (Ajzen, 1991). The TPB focuses on perceived resources that is "an individual believes that he or she has the personal and organizational resources (...) such as skills, hardware, software, money" (Gao and Krogstie, 2008). The TPB explains how individual beliefs affect college students on their intention to adopt mobile devices. Cheon based on TPB model tried to answer two questions: what factors students consider important when adopting $\mathrm{m}$-learning and what is the relationship between these factors in higher education (Cheon, et al., 2012).

Another quantitative research method was the Mobile Learning Attitude Scale (MLAS), used by Gezgin, Adnan and Acar Guvendir (2018) among students of engineering sciences. Using a correlational survey method, they showed a positive attitude toward m-learning. Interesting research (Kim, et al., 2017) was carried out at a university in South Korea using Innovation Diffusion Theory (IDT) and a Model of Innovation Resistance (MIR). IDT describes a psychological characteristic of consumers, as another factor that can explain innovation adoption - such as personalities, attitudes, and values (Kim, Lee. and Rha, 2017). Whereas MIR is defined 'as consumers' resistance to change when adopting an innovation" (Ram, 1987).

Structural equation results revealed that inertia had the most significant effects on students' mobile learning resistance.

Mobile learning in the university's strategy is another interesting area of research. The focus of researchers is how to promote mobile learning at the university among teachers and students - namely, what are the critical success factors? (Lam, Kowk and Wong, 2011) Research carried out by Christensen and Knezeck (2017) shows that teachers must have professional support in introducing mobile learning and that supervisors must 
appreciate their efforts. Acceptance of mobile teaching by teachers is critical during the implementation of $\mathrm{m}$ learning systems (Al-Emran, Elsherif and Shaalan., 2016). Not only teaching but also many administrative activities can be accomplished with the use of mobile devices: attendance lists, applications to the dean's office, surveys (Cheon, et al., 2012). Offering mobile learning can also solve the problem of high student retention (Al Fahad, 2009). Evan Fox from Purdue University points out (Fox, 2019) that mobile devices can help prepare students for intercultural communication and for competition on the global market. Through the use and research of mobile learning, universities can obtain a huge amount of data for analysis, which allows them in turn to design a better educational offer (Topolewski, et al., 2013). Ally and Prieto-Blazquez emphasize that mobile learning should not only focus on technological issues that often change. Mobile learning should primarily be focused on the student and on developing new pedagogical strategies (Ally and Prieto-Blazquez ,2014).

\section{World statistics}

\subsection{World mobile trends}

The Global Digital 2019 report (TGD, 2019) shows relevant statistics on mobile trends. There are 5.11 billion single mobile users in the world today, up by two per cent ( 100 million) in the past year. Mobile internet users comprise $52 \%$ percent of the total population, and the way of using the internet changes year by year. The mobile devices and the mobile internet affect many aspects of the learning and teaching processes. It is worth emphasizing that mobile phone use accounts for almost half of the time that people spend on the internet, and the trend is growing (the share of mobile phones in the total internet time: 2017 - 39\%, 2018 - 45\%, 2019-48\%). In addition, the time spent online is on average over 6.5 hours a day, which amounts to over 100 days per year online. The percentage of mobile connections that can be classified as 'broadband' - i.e. $3 G$ and higher significantly increased to $71 \%$. In education, this means that a university can offer rich multimedia applications for students. According to the GSMA Intelligence Association, which is a definitive source of global mobile data (GSMA, 2018), the global smartphone adoption (smartphone connections as a percentage of total mobile connections) will reach $80 \%$ by 2025 . Another factor conducive to mobile learning is the size of mobile device screens. The bigger screen means easier use of multimedia content and navigation, and consequently, larger screen size smartphones have dominated the market. Over $59 \%$ of smartphone traffic comes from phones larger than five inches, and the 5.5"- to 6"-screen size is the most popular size, amounting to $43.3 \%$ of all phones in use in 2017 (ScientiaMobile, 2017).

\subsection{Mobile applications trends}

The latest figures show a nine per cent increase in downloads of mobile applications compared to 2017. During 2018 alone, users downloaded 194 billion applications in total, and the average user spent USD\$20.15 on mobile applications per smartphone (Dogtiev, 2019). The most popular non-education applications include games, social media, auctions, music, maps, and advertising. In May 2019 the Apple App Store listed its most popular application categories as games $24.63 \%$; business $9.76 \%$; education $8.52 \%$ and lifestyle $8.33 \%$ (Statista, 2019). In Poland, the ranking of the most frequently used applications is similar (TechJury, 2019). The forecast for 2022 in mobile applications downloaded is 258.2 billion (Statista, 2019). Because mobile applications are cheaper to produce than software installed on a computer and thus also cheaper to buy, the market is constantly evolving. Users aged 18-24 years spend 3.2 hours a day using 'apps', those aged 25-34 up to 2.6 hours - which results respectively in 93.5 hours and 85.6 hours per month (TechJury, 2019). The average user has over 80 'apps' installed on his phone but uses 9 daily and 30 monthly. Users find them mainly through the recommendation of family/friends (51\%), search in app stores (51\%), or recommendations from stores $(48 \%)$.

\subsection{Mobile education applications trends}

Educational applications are available for every level of education and are therefore very diverse in both content and architecture. The most popular are: multipurpose learning platforms, specific learning subjects, supportive applications, educational games, learning management applications, and educational applications for preschoolers and toddlers (Quora, 2018). The most popular educational applications in the U.S. according to what gets downloaded are: Remaind (mobile messaging platform in K-12 schools), Photomath ('camera calculator', which shows a step-by-step onscreen solution), Duolingo (for learning languages), Google Classroom (free service for schools), Class Dojo (a classroom communication application is used to share reports between parents and teachers), Kahoot! (a game-based learning platform with multiple-choice quizzes), Quizlet (allows learning information via learning tools and games), Google Arts \& Culture (it allows people to discover art by 
presenting artists, techniques, and trends in art), Peak (games for brain training), and Canvas Student (mobile app for Canvas platform) (SensorTower, 2019).

\subsection{Use of Information and Communication Technologies and mobile devices by Polish students}

Interesting data pertaining to this research have been collected by Eurostat (Eurostat, 2019), concerning Internet and Information and Communication Technologies (ICT) use among students from Poland and the European Union (EU-28). The level of digital skills is high: $89 \%$ of Polish students have basic or above basic overall digital skills, whereas $87 \%$ overall in the EU. Of Polish students, only $1 \%$ have no digital skills and $10 \%$ have low digital skills, equal to the $10 \%$ low skills among students in the EU in general. It is not surprising that almost every student in Poland (94\%) uses a smartphone with access to the Internet.

Table 1: Devices used by students to access the internet

\begin{tabular}{|l|l|l|}
\hline Type of devices & EU-28 & Poland \\
\hline desktop computer & $48 \%$ & $47 \%$ \\
\hline laptop or netbook & $73 \%$ & $79 \%$ \\
\hline tablet computer & $35 \%$ & $23 \%$ \\
\hline mobile phone or smart phone & $95 \%$ & $94 \%$ \\
\hline mobile device & $97 \%$ & $99 \%$ \\
\hline other mobile devices (e.g. media or games player, e-book reader, smart watch) & $18 \%$ & $11 \%$ \\
\hline
\end{tabular}

Source: Eurostat 2018

Polish students in comparison to European colleagues less frequently use the tablet as a device to access the Internet (only 23\%). Other types of mobile devices such as media or games player, e-book reader, and smartwatch are used by only $11 \%$ of students from Poland, which proves that the main efforts related to mobile education at the moment should be directed to the use of smartphones (if the university develops a strategy for implementing m-learning). For teaching, it is important that $90 \%$ of students in Poland use phones with access to the Internet while they are away from home and university.

Table 2: Mobile internet access

\begin{tabular}{|l|l|l|}
\hline Devices used to access the internet away from home or work & EU & Poland \\
\hline laptop, notebook, netbook or tablet computer & $42 \%$ & $35 \%$ \\
\hline portable computer or a handheld device & $93 \%$ & $92 \%$ \\
\hline mobile phone (or smart phone) & $91 \%$ & $90 \%$ \\
\hline other than a mobile phone or a portable computer & $7 \%$ & $7 \%$ \\
\hline
\end{tabular}

Source: Eurostat 2018

Students' internet activities are shown in Table 3. Only 38\% of Polish students use Internet resources for any educational activity (59\% in EU-28). Also, learning from online courses is not popular (7\% of users). The reason may be low student awareness and low availability of good quality online courses in one's native language. The Polish Ministry of Higher Education opened the first platform with MOOC courses (http://navoica.edu.pl/) in 2018, and the content will appear gradually only from the very end of 2019. The second reason could also be the lack of e-learning infrastructure at some universities. Online learning is also often optional.

Table 3: Students' internet activities

\begin{tabular}{|l|l|l|}
\hline Internet use: & EU & Poland \\
\hline doing an online course (of any subject) & $13 \%$ & $7 \%$ \\
\hline online learning material & $45 \%$ & $28 \%$ \\
\hline communicating with instructors or students using educational websites/portals & $39 \%$ & $20 \%$ \\
\hline any of the learning activities & $59 \%$ & $38 \%$ \\
\hline sending/receiving e-mails & $87 \%$ & $88 \%$ \\
\hline telephoning or video calls & $67 \%$ & $64 \%$ \\
\hline uploading self-created content to any website to be shared & $59 \%$ & $61 \%$ \\
\hline
\end{tabular}




\begin{tabular}{|l|l|l|}
\hline Internet use: & EU & Poland \\
\hline playing or downloading games & $58 \%$ & $53 \%$ \\
\hline listening to music (e.g. web radio, music streaming) & $85 \%$ & $88 \%$ \\
\hline watching video on demand from commercial services & $47 \%$ & $25 \%$ \\
\hline watching video content from sharing services & $83 \%$ & $80 \%$ \\
\hline
\end{tabular}

Source: Eurostat (2018-2017)

\section{Research project}

The strategy presented in this article is the result of a two-year research project, and we call it the adoption of mobile solution in context of university teaching. The project consists of six stages, as shown in Figure 1.

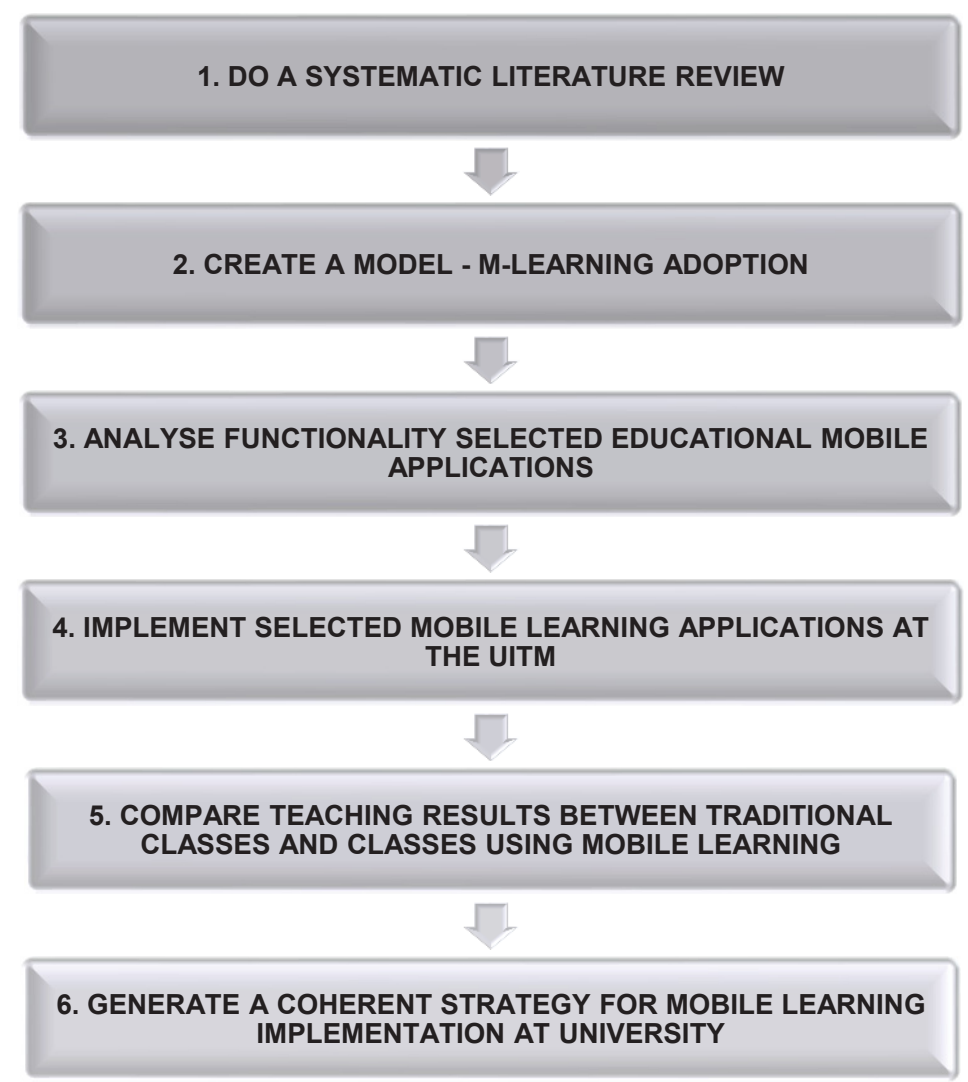

Figure 1: The project: the adoption of mobile solutions in the context of university teaching

STAGE 1. The goal of the systematic literature review has familiarized us with present-day solutions and strategies of m-learning used at universities worldwide. This general overview of the field of interest helps us not only to learn about the existing models of adopting mobile learning at universities but also to create a new model tailored to the needs of UITM. The tool chosen for the systematic literature review is the web-based analysis server Hammer - nailsproject.net (Knutas et al., 2015).

STAGE 2. Understanding students' approach toward using mobile learning at the university. The results of this step should reveal the adoption of mobile learning at the UITM. Are students technologically prepared for mobile learning? What is their attitude towards mobile learning? A questionnaire was designed for the purpose of obtaining the answers to these questions. We also have to analyse teachers' technological maturity and approach to teaching with mobile devices, asking primarily into whether teachers are familiar with new mobile devices and applications. (Hsieh and Tsai, 2017).

STAGE 3. This stage involves the analysis of the functionality selected educational mobile applications (apps) available to the mobile education targets. The analysis will focus on the apps connected with the subjects which the authors of this article teach: mathematics, operation research or statistics. The identification of educational 
apps to be implemented in classes will help in educational content personalization, motivating students to learn and improve the curriculum.

STAGE 4. The fourth stage is the implementation of selected mobile learning applications at UITM. Qualitative research lets us create optimal educational applications, brand-new applications tailored to specific situations, instead of choosing random applications from existing ones. Our model of educational application will be developed from two perspectives: content and technology. The content involves the structure, the kind of interactions, and exercises. The technology involves the computing platform and the style of content display.

STAGE 5. This stage consists of a comparative analysis of results obtained during two semesters from students who used mobile learning and from students who had traditional lessons, using data from the Uczelnia XP system.

STAGE 6. The final step is to generate a coherent strategy for the implementation of m-learning at the university. The foregoing five stages of collected data and two years' research experience in different aspects of mobile learning led the authors to design a general strategy to be implemented at universities aiming to introduce the use of mobile devices into their curriculum. The key factors which qualify a university for effective implementation of mobile learning - e.g. university profile, curriculum profile and students' profile - will need to be identified (Moreira, et al., 2017).

In this article we describe the first step of Stage 2: the technological maturity of the end consumer of mobile learning - the students' perspective.

\section{Research methodology}

The research population consists of students from UITM. The University has 5,157 students from the following countries: Bangladesh, Belarus, Bulgaria, China, Egypt, France, Germany, Hong Kong, India, Jordan, Kazakhstan, Kyrgyzstan, Malaysia, Morocco, Nigeria, Poland, Russia, Spain, Tajikistan, Thailand, Turkey, Ukraine, USA, Vietnam, and Zimbabwe. Almost $12.5 \%$ (640) of the overall student population participated in the research 397 from Poland, 97 from Kazakhstan, 81 from Ukraine and 65 from other countries. The survey was conducted from 1 October 2018 to 27 December 2018. The questionnaire consisted of questions grouped into sections: specifications of mobile devices owned by students and mobile internet access, expectation from mobile education application and attitudes towards current and future use of mobile devices in education. The premodel used in our research is presented in Figure 2. The survey was designed by experts - educators form UITM - with social, ethical, mathematical and IT background.

We decided against digital version of the questionnaires because our experience showed that electronic questionnaires generate a low response rate. We printed the questionnaires and after classes we asked students if they were willing to fill out the form. All students participated voluntarily in the survey and all data were collected anonymously. We assumed that students would express their views and feelings honestly and reliably if the form remained anonymous.

The Statistical Package for the Social Sciences - IBM SPSS Statistics 25 (SPSS) - was used to compute all data and analyse the main output. Visualization of our output is represented using MS Excel. All survey variables were provided in a nominal scale; thus, before applying computer analysis, we coded all data, and text-based answers were transformed to numbers. In the next step, we analysed the questionnaire data. Our analysis was based on the descriptive statistics and cross tables with several variables.

The theoretical background of our pre-model is based on three models: TAM, UTAU and TPB. We have not yet run any mobile application to curriculum. Therefore, we could not use these characteristics (for example: easy to use, context or perceived usefulness - that defines how application is used, et cetera) which describe feelings of using the mobile application. Some of the features in these three models are repeated, so in order not to repeat the same feature, when creating our pre-model, we refer to the features of the first - the oldest models.

Our mobile learning adoption pre-model, tailored to the needs of UITM students, consists of six factors (Figure 2): device, mobile internet access, mobile applications related with study subject, expectation from mobile 
education application, willingness to replace notebooks with mobile application, and willingness to replace books with mobile application.

From the TPB model we adopted the following feature: "an individual believes that he or she has resources (...) such as hardware, software, money" (Gao and Krogstie, 2008). It led us to create new pre-model features called devices and mobile internet access. One of the most important factors to establish was whether or not students have mobile devices, as well as what type of internet connections our students use. This was important because some students come from countries where the average annual income per person is in the range of USD \$1200 -8100 , compared to the US, where the annual income average is $\$ 63080$.

In a next step we adopted from UTAU "performance expectancy", which is "the degree to which an individual believes that using the system will help him or her to attain gains in job performance". We translated "job performance" to the university context, calling it "study performance" (Venkatesh et al., 2003) and created feature mobile applications related with the study subject. This feature checked whether students knew of or wished for particular mobile applications related with their study subject.

From the TAM model, we adopted "behavioural intention", which refers to individual expectation from a given application and we hereby created a feature called expectation from mobile education application.

At the end, we checked if our students trust their personal ability to make use of an electronic environment. From the feature "trust" from the TAM model we created two features: willingness to replace notebooks with mobile application, and willingness to replace books with mobile application.

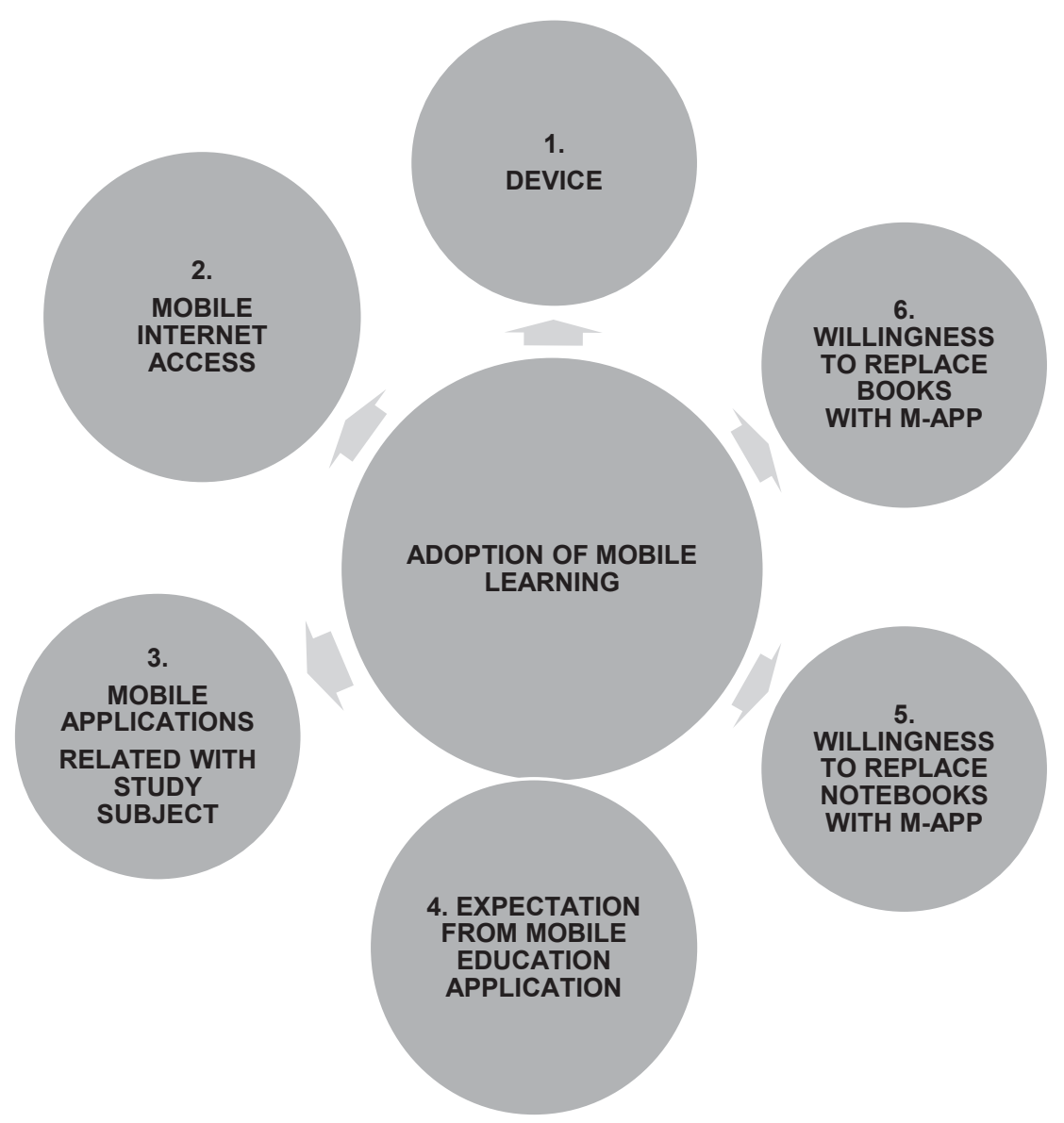

Figure 2: Mobile learning adoption pre-model tailored to needs of UITM students. 


\section{Results}

A total of 640 students, including 322 (50.3\%) female and 318 (49.7\%) male students, participated in the study. At the beginning of our study we checked if students owned mobile devices. The survey indicates that $99.7 \%$ of participants own a smartphone. Furthermore, every student who owns a tablet also owns a smartphone, while just $0.3 \%$ (two students) own neither. We discovered that $17.8 \%$ of the participants own a tablet, with the oldest users often being the tablet owners (Figure 3). The results reflect the world statistics, which also show the growing dominance of smartphones. This does not mean that universities should completely exclude tablets as supporting didactic devices, however, the mobile strategy is mainly meant for smartphones.

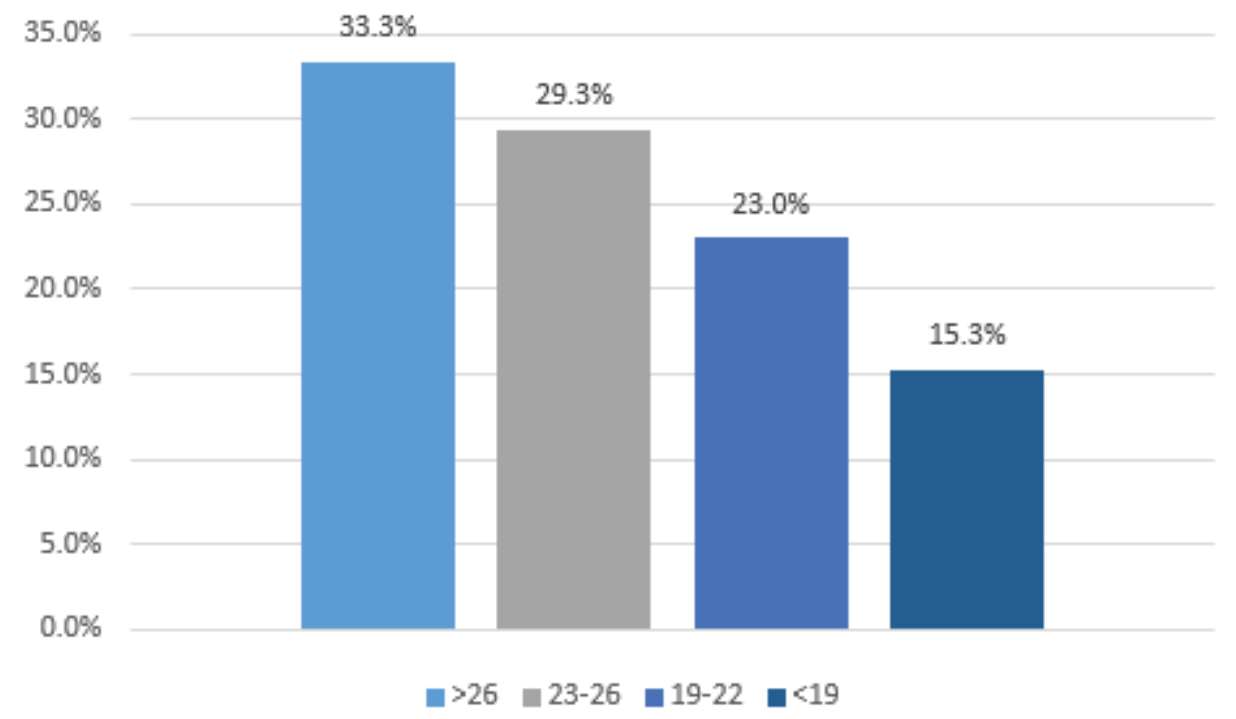

Figure 3: Age of the students versus tablet owners

Almost every fourth student from Poland and Ukraine has a tablet, whereas every sixth from Kazakhstan has this mobile device. The largest percentage of respondents in the study were students from Poland studying in the home country, so it is not surprising they have an unlimited or $10 \mathrm{~GB}$ Internet package. The foreign students' situation is slightly worse $-56.6 \%$ do not have access to mobile internet. For example, almost $35 \%$ of students from Kazakhstan do not have access to mobile Internet. Also, students from Ukraine have an unlimited Internet package less frequently than their Polish colleagues. This does not mean that students do not use the Internet and mobile applications; they often use the university's Wi-Fi network, which allows them to keep private phone numbers and make phone calls (by using such applications as WhatsApp or Viber). Because every modern university provides access to broadband internet, learning from mobile devices during classes is possible. Moreover, in the student housing, students mostly have access to wireless internet. However, the difficulty may be to study in other places, like on the way to the university.

Table 4: Mobile Internet access

\begin{tabular}{|l|l|l|l|l|l|l|l|}
\hline & $\begin{array}{l}\text { up to 250 } \\
\text { Mb }\end{array}$ & $\begin{array}{l}\text { up to 500 } \\
\text { Mb }\end{array}$ & up to 2 GB & $\begin{array}{l}\text { up to 10 } \\
\text { GB }\end{array}$ & $\begin{array}{l}\text { I haven't } \\
\text { got mobile } \\
\text { Internet } \\
\text { pack }\end{array}$ & $\begin{array}{l}\text { I don't } \\
\text { know }\end{array}$ \\
\hline Ukrainians & $4.9 \%$ & $4.9 \%$ & $25.9 \%$ & $32.1 \%$ & $13.6 \%$ & $12.3 \%$ & $6.2 \%$ \\
\hline Polish & $0.8 \%$ & $1.8 \%$ & $17.6 \%$ & $32.7 \%$ & $37.8 \%$ & $2.8 \%$ & $6.5 \%$ \\
\hline Kazakhs & $1.0 \%$ & $4.1 \%$ & $8.2 \%$ & $27.8 \%$ & $16.5 \%$ & $34.0 \%$ & $8.2 \%$ \\
\hline Others & $1.4 \%$ & $2.5 \%$ & $17.0 \%$ & $32.7 \%$ & $29.1 \%$ & $10.3 \%$ & $7.0 \%$ \\
\hline
\end{tabular}

In the open question, students were asked about the most frequently used educational mobile applications related to their field of study, to which $45 \%$ of the students responded that there were educational applications related to their field of study but unfortunately did not provide any particular names. Information provided by students is shown in Table 5. Students mainly use an application to manage their learning process (Muczelnia). 
In addition, because of the university's high level of internationalization, the apps for learning foreign languages were among the most frequently mentioned.

Table 5: Mobile applications related with study subject

\begin{tabular}{|l|l|l|}
\hline $\begin{array}{l}\text { The name of the } \\
\text { application }\end{array}$ & $\begin{array}{l}\text { The percentage of students } \\
\text { (among those who responded) }\end{array}$ & Description \\
\hline Muczelnia & $20,10 \%$ & $\begin{array}{l}\text { A mobile application for students and teachers with } \\
\text { lessons schedule, grades, consultations hours, etc. }\end{array}$ \\
\hline Khan Academy & $11,48 \%$ & $\begin{array}{l}\text { A mobile application for the Khan Academy website } \\
\text { containing teaching materials for a wide range of } \\
\text { school subjects. }\end{array}$ \\
\hline Dictionary & $11,48 \%$ & Various types of dictionaries. \\
\hline TED & $9,57 \%$ & $\begin{array}{l}\text { The application allows the use of TED talks with } \\
\text { subtitles translated into over 100 languages and } \\
\text { listening to podcasts. }\end{array}$ \\
\hline Duolingo & $9,57 \%$ & An application for learning foreign languages. \\
\hline
\end{tabular}

Students have specific high expectations regarding the content of educational applications (Figure 4): they are namely most interested in using them for presentations, videos with instructions and educational quizzes and less for reading articles or lecture recordings. Surprisingly, relatively not many students reported interest in playing educational games; we assume this is because they have not yet encountered an attractive educational game.

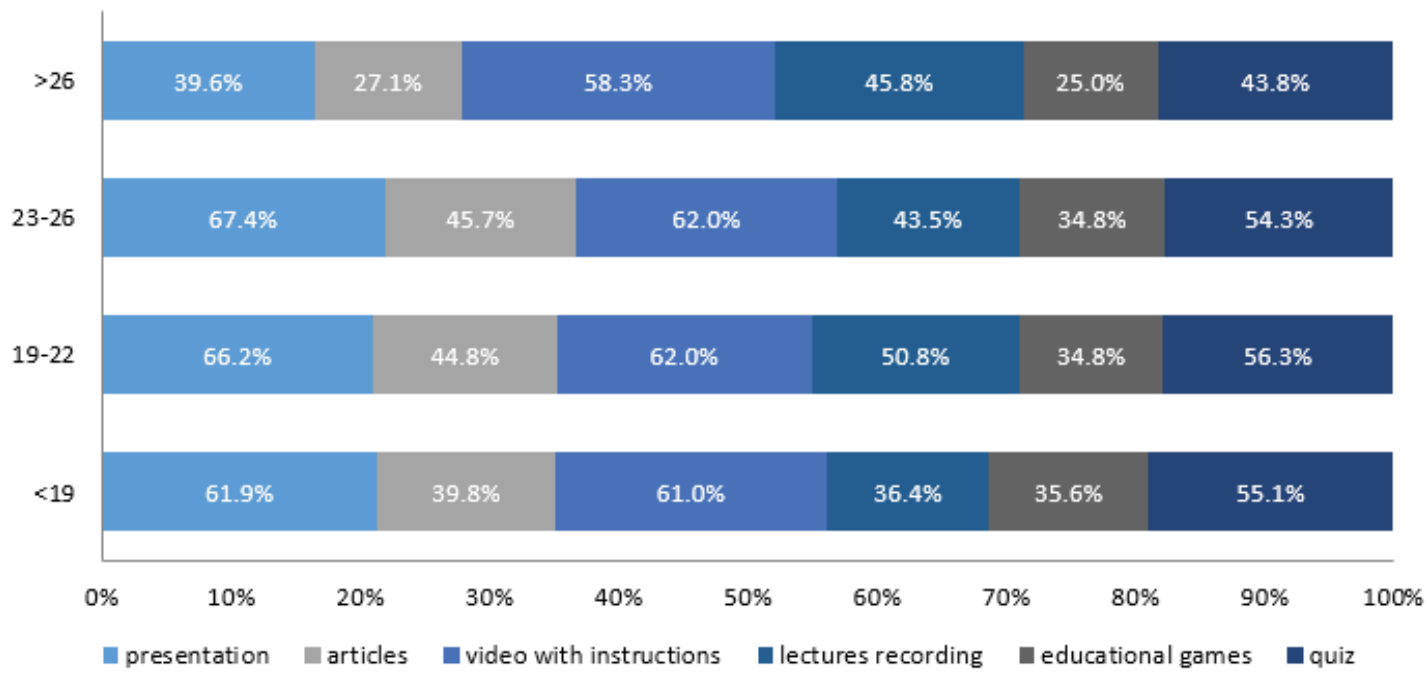

Figure 4: Students' expectations from mobile education content by age

The expectations for the content of the mobile applications depended on the field of study. The high interest in presentations is surprising; students are apparently not thwarted by the usual dry, conventional lecture style lecturers often have. The low position of the games is also astonishing: for many years, UITM has been using decision games in the teaching process. There are games regarding production company management, medical facility management, or supply chain management. In our experience the games are appreciated by students and highly rated, but our questionnaire results did not reflect this.

About half of the students in computer graphics and information technology are not interested in quizzes. This information surprised us a lot. That is why a meeting with deans and teachers of the Information Technology Department and Computer Graphics Department was conducted to discuss this phenomenon. We have determined that the knowledge checking in laboratory on computer graphics and computer science, is based on extensive practical tasks probably due to the practical nature of the classes with specialized software. During the conversation it turned out that teachers in both Departments use tools such as Mentimeter, Kahoot or prepare quizzes on the BlackBoard platform. Therefore, it is understandable that students whom teachers 
provide interesting forms of quizzes are not interested in the next ones. In addition, teachers say that additional quizzes would create among students a sense of being trapped.

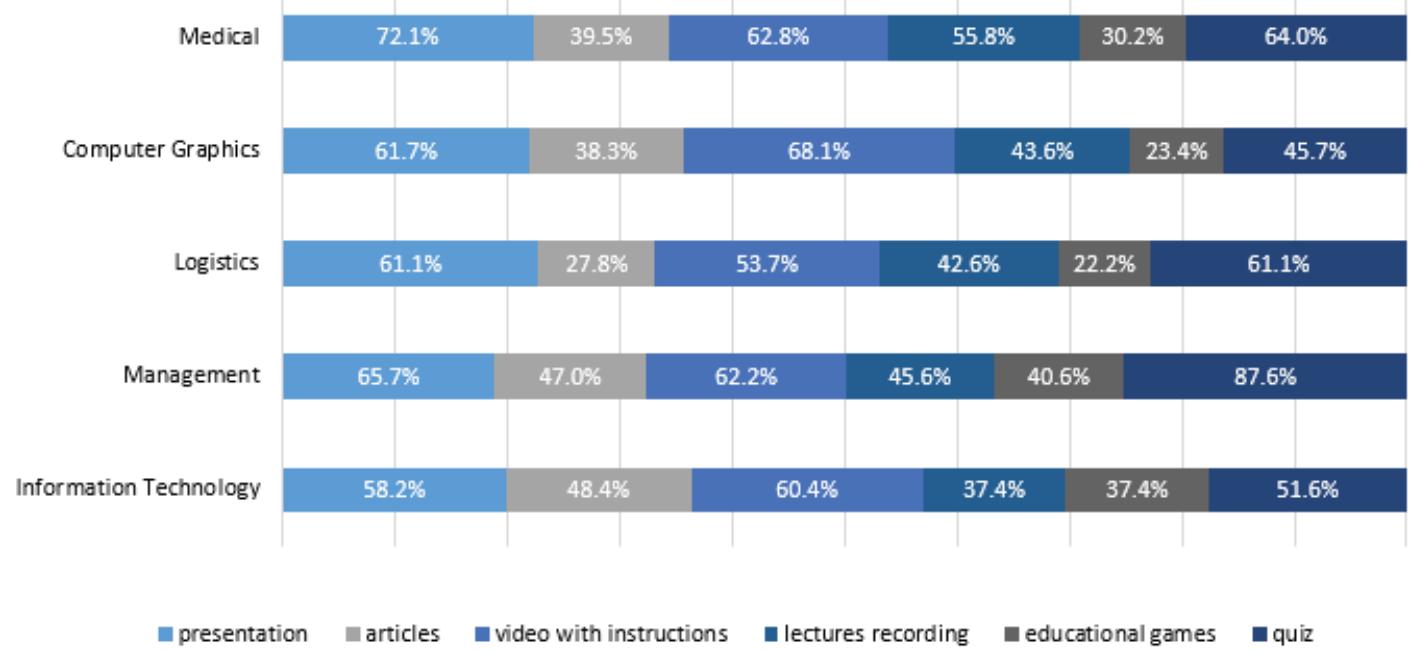

Figure 5: Students' expectations for mobile education content according to field of the study

Regardless of nationality, more than $52 \%$ of students are not ready to do away with traditional books - they are more willing to replace their notebooks with mobile learning tools. Age plays a role here: older students, above 26 , prefer the traditional way of teaching with books and handwritten notes, however, the younger generation seems to be more disposed to using only mobile devices at the university.

Table 6: Willingness to replace book and notebooks

\begin{tabular}{|c|c|c|c|c|}
\hline \multicolumn{3}{|c|}{ Could mobile tools replace books? } & \multicolumn{2}{|c|}{ Could mobile tools replace notebooks? } \\
\hline \multicolumn{5}{|l|}{ Nationality } \\
\hline & Yes & no & yes & no \\
\hline Polish & $43.6 \%$ & $56.4 \%$ & $55.9 \%$ & $44.1 \%$ \\
\hline Kazakhs & $45.4 \%$ & $54.6 \%$ & $53.6 \%$ & $46.4 \%$ \\
\hline Ukrainians & $48.0 \%$ & $52.0 \%$ & $54.3 \%$ & $45.7 \%$ \\
\hline Others & $44.6 \%$ & $55.4 \%$ & $44.6 \%$ & $55.4 \%$ \\
\hline \multicolumn{5}{|l|}{ Age } \\
\hline$>26$ & $31.3 \%$ & $68.8 \%$ & $39.6 \%$ & $60.4 \%$ \\
\hline $23-26$ & $52.2 \%$ & $47.8 \%$ & $54.3 \%$ & $45.7 \%$ \\
\hline $19-22$ & $43.5 \%$ & $56.5 \%$ & $56.3 \%$ & $43.7 \%$ \\
\hline$<19$ & $47.5 \%$ & $52.5 \%$ & $53.4 \%$ & $46.6 \%$ \\
\hline
\end{tabular}

\section{Conclusions}

The development of information technologies opens up great opportunities for new ways of delivering education. Global statistics show rapid growth in the number of mobile devices and mobile education applications. Moreover, international reports indicate the positive impact of iPad use in teaching and learning. The adoption of new technologies into classrooms therefore seems unavoidable, which is forcing university authorities to create pedagogical strategies to implement m-learning in classes. In this context, applying mobile learning tools in the curriculum will help students gain new competences and skills to adapt to the expectations of future employers.

The adoption of mobile learning among UITM students pre-model we used led us to discover that students of the University of Information Technology and Management (UITM) in Poland are technologically and mentally ready for m-learning. The survey indicates that $99.7 \%$ of participants own a smartphone. Our fears that foreign 
students do not have mobile learning devices have not come true. However, an ethical problem arises: What to do when students do not have mobile devices? Should the University provide them with them? Should the requirement to have mobile devices be included in the contract signed when the student is admitted to the university? $45 \%$ of the students responded that there were educational applications related to their field of study but unfortunately did provide names of applications loosely related to the field of study. This shows that the university needs to demonstrate relevant applications. When designing educational applications, a lot of emphasis should be placed on lecture recordings, video with instructions and professional presentations because this is what our students expect. Because more than $52 \%$ of students are not ready to do away with traditional books, we will try to show students the benefits of digital content. The m-learning strategy will increase the status of UITM as a technologically developed university.

\section{References}

Ajzen, I., 1991. The theory of planned behavior. Organizational Behaviour and Human Decision Processes, 50, pp.179-211. Al-Emran, M., Elsherif, M. H. and Shaalan, K., 2016. Investigating attitudes towards the use of mobile learning in higher education. Computers in Human Behavior, 56, pp. 93-102.

Al-Fahad, F. N., 2009. Students' attitudes and perceptions towards the effectiveness of mobile learning in King Saud University, Saudi Arabia. Online Submission, 8(2).

Ally, M. and Prieto-Blázquez, J., 2014. What is the future of mobile learning in education?. International Journal of Educational Technology in Higher Education, 11(1), pp. 142-151.

Bano, M., Zowghi, D., Kearney, M., Schuck, S. and Aubusson, P., 2018. Mobile learning for science and mathematics school education: A systematic review of empirical evidence. Computers \& Education, 121, pp. 30-58.

Briz-Ponce, L., Pereira, A., Carvalho, L., Juanes-Méndez, J. A. and García-Peñalvo, F. J., 2017. Learning with mobile technologies-Students' behavior. Computers in Human Behavior, 72, pp. 612-620.

Cheon, J., Lee, S., Crooks, S. M. and Song, J., 2012. An investigation of mobile learning readiness in higher education based on the theory of planned behavior. Computers \& Education, 59(3), pp. 1054-1064.

Christensen, R. and Knezek, G., 2017. Readiness for integrating mobile learning in the classroom: Challenges, preferences and possibilities. Computers in Human Behavior, 76, pp. 112-121.

Cole, H. and Stanton, D., 2003. Designing mobile technologies to support co-present collaboration. Personal and Ubiquitous Computing, 7(6), pp. 365-371.

Crompton, H. and Burke, D., 2018. The use of mobile learning in higher education: A systematic review. Computers \& Education, 123, pp. 53-64.

Davis, F., Bagozzi R. and Warshaw ${ }_{2}$ P., 1989. User Acceptance of Computer Technology: A Comparison of Two Theoretical Models. Management Science, 35 (8), pp. 982-1003

Dogtiev A., 2019. App Download and Usage Statistics. [online] Available at: <http://www.businessofapps.com/data/app-statistics> [Accessed 6 June 2019].

Eurostat Database, 2019. [online] Available at: < https://ec.europa.eu/eurostat/data/database > [Accessed 5 May 2019].

GSMA Intelligence, 2018. Global Mobile Trends. What's driving the mobile industry? [online] Available at: <https://www.gsmaintelligence.com/research/?file=8535289e1005eb248a54069d82ceb84> [Accessed 5 May 2019].

Fiallos, D., Chavez, J., Mendoza, L. and Campana, J., 2017. Technologies in Higher Education: Public Policies and Social Appropriation of their Implementation, Revista Digital de Investigacion en Docencia Universitaria, 11(1), pp. 193-206.

Fox, E., 2019. Mobile Technology: A Tool to Increase Global Competency among Higher Education Students. International Review of Research in Open and Distributed Learning, 20(2), pp. 242-259.

Frohberg, D., Göth, C. and Schwabe, G., 2009. Mobile learning projects-a critical analysis of the state of the art. Journal of computer assisted learning, 25(4), pp. 307-331.

Gao, S., Krogstie, J., 2008. Mobile Services Acceptance Model. Convergence and Hybrid Information Technology, ICHIT '08, doi: 10.1109/ICHIT.2008.252.

Gezgin, D. M., Adnan, M. and Acar Guvendir, M., 2018. Mobile learning according to students of computer engineering and computer education: A comparison of attitudes. Turkish Online Journal of Distance Education, 19(1), pp. 4-17.

Gikas, J. and Grant, M. M., 2013. Mobile computing devices in higher education: Student perspectives on learning with cellphones, smartphones \& social media. The Internet and Higher Education, 19, pp. 18-26.

Grant, M. M., 2019. Difficulties in defining mobile learning: analysis, design characteristics, and implications. Educational Technology Research and Development, 67(2), pp. 361-388.

Hamidi, H. and Chavoshi, A., 2018. Analysis of the essential factors for the adoption of mobile learning in higher education: A case study of students of the University of Technology. Telematics and Informatics, 35(4), pp. 1053-1070.

Heflin, H., Shewmaker, J. and Nguyen, J., 2017. Impact of mobile technology on student attitudes, engagement, and learning. Computers \& Education, 107, pp. 91-99.

Hopkins, P. and Burden, K., 2014. IPADAGOGY: iPads as drivers of transforming practice in teaching education. Proceedings of the $1^{\text {st }}$ International Conference on the Use of iPads in Higher Education, Cambridge Scholars Publishing, 5.

Hsieh, W.M. and Tsai, C.C., 2017. Taiwanese high school teachers' conceptions of mobile learning, Computers \& Education, 115, pp.82-95. 
Hwang, G. J. and Tsai, C. C., 2011. Research trends in mobile and ubiquitous learning: A review of publications in selected journals from 2001 to 2010. British Journal of Educational Technology, 42(4), pp. E65-E70.

Kim, H. J., Lee, J. M. and Rha, J. Y., 2017. Understanding the role of user resistance on mobile learning usage among university students. Computers \& Education, 113, pp. 108-118.

Korniejenko, K., 2016. Possibility of use of m-learning support for postgraduate courses in welding. Science Notebooks, 48 , University of Science and Technology in Krakow,

DOI: 10.4467/2353737XCT.15.368.4859

Knutas A., Hajikhani A., Salminen J., Ikonen J. and Porras J., 2015. Cloud-Based Bibliometric Analysis Service for Systematic Mapping Studies. In: Proceedings of the 16th International Conference on Computer Systems and Technologies (CompSysTech '15). DOI: 10.1145/2812428.2812442

Lam, P., Kowk, M. and Wong, K., 2011. Support and promotion of mobile learning strategies. Changing Demands, Changing Directions. Proceedings ASCILITE Hobart, pp. 758-762.

Liu, Y., Han, S. and Li, H., 2010. Understanding the factors driving m-learning adoption: a literature review. Campus-Wide Information Systems, 27(4), pp. 210-226.

Macleod, J. and Kefallonitis, E., 2017. Trends Affecting e-Learning Experience Management, 4th International Conference on Strategic Innovative Marketing (IC-SIM), Mykonos, Greece, pp.753-758.

Montrieux, H. and Schellens, T., 2018. The didactical use of tablets: a balancing act between teacher-centred and learnercentred education. In 12th International Technology, Education and Development Conference (INTED) (pp. 37-44).

Moreira, F., Ferreira, M.J., Santos, C.P. and Durao, N., 2017. Evolution and use of mobile devices in higher education: A case study in Portuguese Higher Education Institutions between 2009/2010 and 2014/2015, Telematics and Informatics, 34(6), pp.838-852

Nassuora, A. B., 2012. Students acceptance of mobile learning for higher education in Saudi Arabia. American Academic \& Scholarly Research Journal, 4(2), pp. 24-30.

Quora. 2018. What is the market share of educational apps? [online] Available at:

<https://www.quora.com/What-is-the-market-share-of-educational-apps> [Accessed 6 June 2019]

Ram S., 1987. A Model of Innovation Resistance. Advances in Consumer Research. Vol.14, eds. Melanie Wallendorf and Paul Anderson, Provo, UT: Association for Consumer Research, pp. 208-212.

Report, Digital 2019: global internet use accelerates, [online] Available at: <https://wearesocial.com/blog/2019/01/digital-2019-global-internet-use-accelerates> [Accessed 23 May 2019].

Sanchez P., Olmos M. S. and Garcia-Penalvo F. J., 2017. Will future teachers use mobile technologies? Validation of an extended TAM model proposal, Revista de Educacion a Distancia, 52(5), pp.1-31.

ScientiaMobile, 2017. Smartphone Screen Size Trend [online] Available at: < https://www.scientiamobile.com/smartphone-screen-size-trend> [Accessed 6 June 2019].

SensorTower Blog, 2019. Top Education Apps in the U.S. for 2018 by Downloads [online] Available at: <https://sensortower.com/blog/top-education-apps-us-2018-downloads> [Accessed 6 June 2019].

Statista, 2019. Most popular Apple App Store categories in May 2019, by share of available apps [online] Available at: < https://www.statista.com/statistics/270291/popular-categories-in-the-app-store > [Accessed 6 June 2019].

Sung, Y. T., Chang, K. E. and Liu, T. C., 2016. The effects of integrating mobile devices with teaching and learning on students' learning performance: A meta-analysis and research synthesis. Computers \& Education, 94, pp. 252-275.

TechJury, 2019. 51 Jaw Dropping App Usage Statistics \& Trends [online] Available at: <https://techjury.net/statsabout/app-usage> [Accessed 6 June 2019].

The Global Digital, 2019. [online] Available at: < https://datareportal.com/reports/digital-2019-q2-global-digital-statshot> [Accessed 6 June 2019].

Topolewski, D., Annie, S., Shubo, Y. and Pallachola, S., 2013. Challenges for successful adoption of mobile learning. Global mobile learning implementations and trends, pp. 4-44.

Wu, W. H., Wu, Y. C. J., Chen, C. Y., Kao, H. Y., Lin, C. H. and Huang, S. H., 2012. Review of trends from mobile learning studies: A meta-analysis. Computers \& Education, 59(2), pp. 817-827.

Venkatesh, V., Morris, M. G., Gordon, B. D. and Davis, F. D. 2003. User acceptance of information technology: Toward a unified view. MIS Quarterly, 27(3), 425-478. doi: 10.2190/EC.40.1.d 